\title{
Effect of Water Irrigation from Different Sources on Soil and Plant Properties in Qalyubiya Governorate, Egypt \\ Mohamed, M. M. ${ }^{1}$; A. M. A. Mashhour' ; A. M. M. Abd El-Fattah' ${ }^{2}$ and M. H. Abo - Ziud ${ }^{3}$ \\ ${ }^{1}$ Soils and Water Department, Faculty of Agriculture, Cairo, Al-Azhar University, Egypt. \\ ${ }^{2}$ Soils, Water and Environmental Institute, Agricultural Research Center, Giza, Egypt. \\ ${ }^{3}$ Central Department for Irrigation Advisory Services, Irrigation Department, Ministry of Water Resources and Irrigation, Egypt.
}

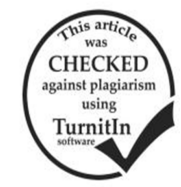

\section{ABSTRACT}

Particularly in dry regions, the scarcity of high-quality fresh water has heightened the importance of urban water re-use. The aim of this research is to evaluate the different of water resources in Qalyubiya Governorate, Egypt, for irrigation purposes. Its bounded by latitudes $30^{\circ} 25^{\prime} \mathrm{N}$ and longtitudes $31^{\circ} 13^{\prime} \mathrm{E}, 17$ meters high above sea level. Taking into consideration the effect of used water on soil properties and accumulation of some elements in plants. Representative water, soil and plant samples were collected from Abu El-Manja canal and Iskandar drain sites, Qalyub area. The results indicated that soil salinity increased due to the application of drainge water in irrigation, howevere Rice plants diminshed the salinity effect. It is observed that the concentration of $\mathrm{Pb}, \mathrm{Zn}$ and $\mathrm{Cu}$ increased in Onion and rice plants either irrigated by canal water or drainage water. No significance differnent in soil physical properties were observed in both study sites.

Keywords: heavy metals, water quality, soil properties

\section{INTRODUCTION}

The dawn of the industrial revolution forced the mankind to introduce numerous hazardous compounds into the environment at an exponential rate. The hazardous pollutants consist of a variety of organic compounds and heavy metals. The quality of irrigation water plays an important role in agricultural development and requires management for maintaining an optimum salt balance in the root zone for productive agriculture. The effect of irrigation with low quality water is shown on both soil physical and chemical properties, as well as on growth and concentration of heavy metals in plants, (Malla et al. 2007)

Many studies were conducted to evaluate these effects, Alobaidy et al. (2010) found that the monitoring periodic of the quality of treated wastewater used in irrigation is necessary to avoid changes in soil chemical properties in the long term. El Bouraie et al. (2011) found that the water of El-Rahawy drain is one of the main drains, which outlet on Rosetta branch, Nile delta, Egypt, and receives considerable waste waters from Greater Cairo area it is considered a serious source of nitrate contamination and high concentrations of elements exceeding the permissible Egyptian and international standards. The periodic monitoring of the quality of this water is necessary to detect pollution flows and to restrict its environmental impacts. Singh and Agrawal (2012) reported that the long-term irrigation with waste water led to the soil $\mathrm{pH}$ decreased, whereas organic $\mathrm{C}$, total $\mathrm{N}$, available $\mathrm{P}$, and exchangeable cations increased at irrigated sites as compared to the soil irrigated by clean water. Goher et al. (2014) pointed out that the Ismailia canal is exposed to deterioration in its water quality because it passes through many towns and villages where some the discharged waste is thrown into the waterway. Alghobar and Suresha (2017) found that the irrigation with different qualities of wastewater influenced the concentration of total nitrogen in the soil irrigated with sewage water and treated sewage water as compared to the control ground water.

For the effects on soil physical properties, Abd ElMawgoud (2005) reported that the result of using drainage water for irrigation, the drainable and water holding pores decreased, consequently fine capillary pores increased. Emdad et al. (2006) found that the irrigation water quality has been affect significantly the soil physical properties. Where high sodium levels combined with low soil-water electrical conductivity can lower a soil's permeability through the swelling and dispersion of clays and the slaking of the aggregates. Also, Subramani et al. (2014) found that the continuous irrigation with wastewater has improved the soil physical properties as water retention and hydraulic conductivity.

Khan et al. (2008) showed that the heavy metals concentrations in plants grown in wastewater irrigated soils was significantly higher than in plants grown in the reference soil and exceeded the permissible limits. Gupta et al. (2008) revealed that heavy metals were beyond the safe limits in vegetables grown in wastewater-irrigated areas may pose public health hazards. Saffari and Saffari (2013) showed an increasing in $\mathrm{N}, \mathrm{P}, \mathrm{K}, \mathrm{Zn}, \mathrm{Cu}, \mathrm{Zn}$, and $\mathrm{Mn}$ concentrations in grain and frond of beans which is irrigated by wastewater as compared to the control treatment water. Khaskhoussy et al. (2013) showed that sewage water irrigation treatments increased the availability of phosphorus and microelements i.e ( $\mathrm{Fe}, \mathrm{Mn}, \mathrm{Zn}$ and $\mathrm{Cu}$ ) to plant which lead to increase of cauliflower and red cabbage yields. Pandey (2006) found that an increase in the accumulation of heavy metals in the irrigated plants compared to the irrigated plants with $50 \%$ reduced industrial waste therefore the waste must be treated before use in irrigation to avoid the resulting health risks.

In the present study, an attempt was made to study the effect of the environmental changes such as human practices and urban creeping on water quality of different resources, soil properties and crop yield. For this, the Qalyub areas, Qualubia Governorate, Egypt, were considered. These areas dependent on the Abu El-Manja canal and Iskander drain in the irrigation of agricultural lands. Now it is conveying many cities sewage, industrial, agricultural and domestic wastes. Today it is one of the most contaminated water sources. The crop yield response was evaluated for the study area at the test plots at the areas under investigation.

\section{MATERIALS AND METHODS}

The study area is located in Qalyubiya Governorate which lies east of the Nile on the head of the Delta. Its bounded by latitudes $30^{\circ} 25^{\prime} \mathrm{N}$ and longtitudes $31^{\circ} 13^{\prime} \mathrm{E}$. Its bonuded on the north by Governorates Dakahlia and Garbiya, on the south by 
Governorates of Cairo and Giza, on the east by Sharkiya Governorate and on the west by Monofiya Governorate.

Representative water, soil and plant samples were collected from Abu El-Manja canal and Iskandar drain sites. The collected samples were kept in containers that were thoroughly washed and sterilized to avoid any contamination. The collected water samples were taken from along Abu El-Manja canal at the beginning of the canal, Kilometer 2.500, Kilometer 7.600, Kilometer 13.950 and at Kilometer 18.350 respectively according to APHA (1995) method. The collected soil samples $(0-30 \mathrm{~cm})$ were kept in containers then transported to the laboratory for drying, grinding and sieving by a $2 \mathrm{~mm}$ sieve for physical and chemical analyses. Onion and Rice plants were collected from Abu El-Manja canal site. rice plants were collected from Iskandar drain site.

Chemical analysis of water, soil extract and plants was determined according to Page et al. (1982). While, soil physical properties were determined according to Klute (1986).

\section{RESULTS AND DISCUSSION}

The chemical compositions of the collected water samples form Abu El-Manja canal are given in Tables 1 and 2. The results show that the water samples are neutral in reaction (7.1 to 7.7). The ionic content of the water was low, whereas the electrical conductivity ranged from $0.31-0.87$ dS.m ${ }^{-1}$ (TDS from 198 to $557 \mathrm{ppm}$ ), which considered to be suitable for irrigation purposes. In this respect, normal groundwater has a conductance ranging from 30 to 2000 $\mu \mathrm{S} / \mathrm{cm}$ (Davis and Dewiest, 1966). Also, according to Todd and Mays (2004), the water is considered as fresh water when TDS $<1000 \mathrm{ppm}$. The following ionic dominance order mostly prevailed: $\mathrm{SO}_{4}>\mathrm{HCO}_{3}>\mathrm{Cl}>\mathrm{CO}_{3}: \mathrm{Ca}>\mathrm{Mg}>$ $\mathrm{Na}>\mathrm{K}$. Also, it is observed from Table 1, that the calculated of sodium adsorption ratio (SAR) and residual sodium carbonates (RSC) were in the allowed range for using the canal water in irrigation. Whereas the values of SAR for these water samples are ranged from $(0.27-1.13)$ and RSC values were less than zero. As a rule, water that has SAR value below 3 is safe for irrigating all plants. Water that has SAR value greater than 9 , on the other hand, can cause severe permeability problems when applied to soils and should be avoided (Harivandi, 1999).

In general, the studied water salinity, chloride and sodium concentration were within acceptable limit for irrigation. The permissible limit for irrigation of the TDS, $\mathrm{Cl}$ and $\mathrm{Na}$ according to FAO (1985) is $800 \mathrm{mgl}^{-1}, 9 \mathrm{meql}^{-1}$ and $10 \mathrm{meql}^{-1}$.

Table 1. Chemical composition of irrigation water samples from along Abu al-Manja canal (Kilometer from the beginning of the canal).

\begin{tabular}{|c|c|c|c|c|c|c|c|c|c|c|c|c|c|}
\hline \multirow{2}{*}{$\begin{array}{l}\text { Sample } \\
\text { No. }\end{array}$} & \multirow[b]{2}{*}{ Location } & \multirow[b]{2}{*}{ pH } & \multirow{2}{*}{$\begin{array}{c}E C \\
\mathrm{dS} \text { m }^{-1}\end{array}$} & \multicolumn{4}{|c|}{ Soluble cations (meq. $\mathbf{L}^{-1}$ ) } & \multicolumn{4}{|c|}{ Soluble anions (meq. $\left.\mathrm{L}^{-1}\right)$} & \multirow{2}{*}{ RSC } & \multirow[b]{2}{*}{ SAR } \\
\hline & & & & $\mathrm{Na}^{+}$ & $\mathbf{K}^{+}$ & $\mathrm{Ca}^{+}$ & $\mathbf{M g}^{+4}$ & $\mathrm{Cl}^{-}$ & $\mathrm{HCO}_{3}$ & $\mathrm{CO}_{3}=$ & $\mathrm{SO}_{4}=$ & & \\
\hline 1 & K 0.000 & 7.7 & 0.34 & 0.61 & 0.16 & 1.8 & 1.23 & 0.51 & 1.32 & 0.38 & 1.60 & -1.81 & 0.49 \\
\hline 2 & K 2.500 & 7.6 & 0.31 & 0.33 & 0.13 & 1.98 & 0.90 & 0.36 & 1.23 & 0.38 & 1.37 & -1.13 & 0.27 \\
\hline 3 & K 7.600 & 7.4 & 0.43 & 0.82 & 0.21 & 2.2 & 1.44 & 0.51 & 1.60 & 0.38 & 2.22 & -1.70 & 0.6 \\
\hline 4 & K 13.950 & 7.1 & 0.41 & 0.54 & 0.19 & 2.4 & 1.27 & 0.51 & 1.60 & 0.57 & 1.73 & -1.51 & 0.4 \\
\hline 5 & K 18.350 & 7.2 & 0.87 & 1.88 & 0.59 & $3.1 \mathrm{~s}$ & 2.33 & 1.33 & 1.98 & 0.94 & 3.74 & -2.60 & 1.13 \\
\hline
\end{tabular}

Data are present in Table 2 show the concentration of some elements in water samples from along of Abu ElManja canal, generally the results indicated that the elements under investigation in the safe and allowed levels for irrigation according to WHO, (2004), who stated that the normal water contains lower than 50, 0.05, $1 \mathrm{ppm}$ from iron, zinc and fluoride. Also, the recommended maximum according to FAO (1985) for iron, copper, zinc and manganese concentration for irrigation are 5, 0.2, 2.0 and 0.2 ppm respectively.

Table 2. Chemical composition of irrigation water samples from along Abu al-Manja canal (Kilometer from the beginning of the canal).

\begin{tabular}{lccccccccccc}
\hline Sample & \multirow{2}{*}{ Location } & \multicolumn{10}{c}{ Concentration elements (mg L $\mathbf{L}^{-1}$ ) } \\
\cline { 3 - 12 } No. & N & P & K & Fe & Mn & Zn & Cu & Pb & Cd & Ni \\
\hline 1 & K 0.000 & 9.00 & 3.60 & 6.24 & 0.178 & 0.04 & 0.40 & $*<0.1$ & 0.025 & $*<0.1$ & 0.008 \\
2 & K 2.500 & 12.60 & 3.40 & 5.07 & 0.186 & 0.04 & 0.40 & $*<0.1$ & 0.032 & $*<0.1$ & 0.008 \\
3 & K 7.600 & 10.90 & 3.50 & 8.19 & 0.182 & 0.04 & 0.40 & $*<0.1$ & 0.035 & $*<0.1$ & 0.012 \\
4 & K 13.950 & 11.30 & 3.70 & 7.41 & 0.191 & 0.03 & 0.41 & $*<0.1$ & 0.039 & $*<0.1$ & 0.010 \\
5 & K 18.350 & 10.90 & 3.50 & 23.01 & 0.241 & 0.02 & 0.41 & $*<0.1$ & 0.057 & $*<0.1$ & 0.023 \\
\hline
\end{tabular}

The data in Tables 3 and 4 show some chemical properties of collected soil samples from Abu al-Manja canal area, whereas soil reaction is neutral (7.0 to 7.4). It noticed that the EC readings of soil extract increased (1.39 to $4.08 \mathrm{dS} . \mathrm{m}^{-1}$ ) due to the increasing of soluble ions concentration. It is observed that the values of EC increased with the long of the canal in soils planted with Onion, while at the end of canal in Rice field (sample No. 5), the values of EC decreased (1.39 $\left.\mathrm{dS} \mathrm{m}^{-1}\right)$. This may be due to highly water requirements of rice and leaching effect of soluble salts. The calcium carbonate content ranged from 1.79 to 4.0 $\%$. Also, the result in the Table 4 show that the cation exchange capacity (CEC) ranged between 37.51 to 40.61 meq $100 \mathrm{~g}^{-1}$ due to the highly clay content. These variations in values of soil chemical properties may be attributed to the management processes of these locations such as organic manure, crop rotation and water quality.

Tables (4 and 5) show some physical properties of soil under investigation, The data show that the soil texture in most location is silty clay loam and only in the beginning of soil around the canal is silt loam, The higher clay percentage were observed in the surface layers of soil at the end of the canal, bulk density ranged from 1.13 to $1.22 \mathrm{Mg} \cdot \mathrm{m}^{-3}$, total porosity ranged between $53.49 \%$ for the beginning of the canal to $57.35 \%$ for the end of the canal, hydraulic conductivity ranged from 1.5 to $5.4 \mathrm{~cm} \mathrm{~h}^{-1}$ and the higher values were observed in the end of canal and correlated with the quakily drainable pores. The physical analysis of these locations showed that soil physical properties under investigation are suitable for plant growth. 
Table 3. Chemical properties of the collected soils from Abu al-Manja canal area (Kilometer from the beginning of the canal).

\begin{tabular}{|c|c|c|c|c|c|c|c|c|c|c|c|}
\hline \multirow{2}{*}{$\begin{array}{l}\text { Sample } \\
\text { No. }\end{array}$} & \multirow{2}{*}{ Location } & \multirow{2}{*}{$\begin{array}{c}\text { pH } \\
(1: 2.5)\end{array}$} & \multirow{2}{*}{$\begin{array}{c}\mathrm{EC} \\
\mathrm{dSm}^{-1}\end{array}$} & \multicolumn{4}{|c|}{ Soluble cations (meq $\left.\mathrm{L}^{-1}\right)$} & \multicolumn{4}{|c|}{ Soluble anions $\left(\mathrm{meq}^{-1}\right)$} \\
\hline & & & & $\mathrm{Na}^{+}$ & $\mathbf{K}^{+}$ & $\mathrm{Ca}^{+}$ & $\mathbf{M g}^{+F}$ & $\mathrm{Cl}^{-}$ & $\mathrm{HCO}_{3}$ & $\mathrm{CO}_{3}{ }^{2}$ & $\mathrm{SO}_{4}{ }^{=}$ \\
\hline$\overline{1}$ & K 2.500 & 7.2 & 3.65 & 7.20 & 0.68 & 25.0 & 6.52 & 3.22 & 4.72 & - & 31.46 \\
\hline 2 & K 7.600 & 7.0 & 4.38 & 7.93 & 0.76 & 27.6 & 11.15 & 5.37 & 4.72 & - & 37.38 \\
\hline 3 & K 13.950 & 7.4 & 4.55 & 7.60 & 0.76 & 26.32 & 14.99 & 7.37 & 4.72 & - & 37.58 \\
\hline 4 & K 18350 & 7.1 & 4.95 & 9.00 & 0.84 & 31.58 & 11.90 & 5.51 & 4.72 & - & 43.09 \\
\hline 5 & 几 10.550 & 7.4 & 1.39 & 4.43 & 0.19 & 7.89 & 2.97 & 8.05 & 4.25 & - & 3.18 \\
\hline
\end{tabular}

* Cite No 5 cultivated with Rice, the rest cites cultivated with Onion.

Table 4. Some physical and chemical properties of the collected soils from Abu al-Manja canal area (Kilometer from the beginning of the canal).

\begin{tabular}{|c|c|c|c|c|c|c|c|c|c|}
\hline $\begin{array}{l}\text { Sample } \\
\text { No. }\end{array}$ & Location & $\begin{array}{r}\text { Particle } \\
\text { Sand }\end{array}$ & $\begin{array}{l}\text { e dist } \\
\text { Silt }\end{array}$ & $\begin{array}{l}\text { tion }(\%) \\
\text { Clay }\end{array}$ & Textural class & $\underset{\%}{\mathrm{CaCO}_{3}}$ & $\begin{array}{l}\text { SP } \\
\%\end{array}$ & ESP & $\begin{array}{c}\text { CEC } \\
\mathrm{meg} / 100 \mathrm{~g}\end{array}$ \\
\hline & K 2.500 & 19.4 & 56.0 & 24.6 & Silt loam & 2.55 & 54.5 & 1.31 & 37.51 \\
\hline & K 7.600 & 18.4 & 53.0 & 28.6 & Silt clay loam & 4.08 & 59.0 & 10.07 & 38.41 \\
\hline & K 13.950 & 17.4 & 52.0 & 30.6 & Silt clay loam & 2.21 & 63.0 & 2.10 & 39.02 \\
\hline & $V 10250$ & 14.4 & 50.0 & 35.6 & Silt clay loam & 1.79 & 64.0 & 1.64 & 40.13 \\
\hline 5 & K 18.550 & 14.4 & 50.0 & 35.6 & Silt clay loam & 3.32 & 72.5 & 4.37 & 40.61 \\
\hline
\end{tabular}

Cite No 5 cultivated with Rice, the rest cites cultivated with Onion.

Table 5. Physical properties of the collected soils from Abu al-Manja canal area (Kilometer from the beginning of the canal).

\begin{tabular}{|c|c|c|c|c|c|c|c|c|c|}
\hline \multirow[b]{2}{*}{$\begin{array}{l}\text { Sample } \\
\text { No. }\end{array}$} & \multirow[b]{2}{*}{ Location } & \multirow[b]{2}{*}{$\underset{\mathbf{M g m}^{-3}}{\text { B.D }}$} & \multirow[b]{2}{*}{$\begin{array}{l}\text { T.P } \\
(\%)\end{array}$} & \multirow[b]{2}{*}{$\begin{array}{c}\text { H.C } \\
\mathrm{cm} \mathrm{h}^{-1}\end{array}$} & \multirow[b]{2}{*}{$\underset{\%}{\text { A.W }}$} & \multicolumn{4}{|c|}{ Pore size distribution $(\mu \mathrm{m})$} \\
\hline & & & & & & $\begin{array}{c}\text { QDP > } \\
28.8\end{array}$ & $\begin{array}{c}\text { SDP } \\
28.8-8.6\end{array}$ & $\begin{array}{c}\text { WHP } \\
8.6-0.19\end{array}$ & $\begin{array}{c}\text { FCP }< \\
0.19\end{array}$ \\
\hline$\overline{1}$ & K 2.500 & 1.22 & 53.49 & 2.2 & 16.00 & 18.06 & 3.30 & 29.62 & 2.51 \\
\hline 2 & K 7.600 & 1.20 & 54.71 & 2.5 & 16.12 & 18.43 & 4.69 & 30.67 & 3.15 \\
\hline 3 & K 13.950 & 1.18 & 55.47 & 3.1 & 15.52 & 19.65 & 6.36 & 30.88 & 3.49 \\
\hline 4 & $K 18250$ & 1.15 & 56.60 & 5.4 & 15.36 & 20.76 & 5.65 & 31.07 & 2.92 \\
\hline 5 & K 18.350 & 1.13 & 57.35 & 1.5 & 17.61 & 16.98 & 5.59 & 32.17 & 3.23 \\
\hline
\end{tabular}

The concentration of some nutrients and heavy metals in soil are present in Table 6, the data show that the concentration in the safe and allowed levels in soil according to FAO (1985) for iron, copper, zinc and manganese concentration for irrigation are 5, 0.2, 2.0 and $0.2 \mathrm{ppm}$ respectively. The values of macronutrients showed that the available $\mathrm{N}$ and $\mathrm{K}$ in the suitable limits but available $\mathrm{P}$ lower than the critical limits (10-250 according to Horneck et al. (2011).

Concerning to the effect of irrigation water on the content of some elements in onion plants (samples No. 1, 2, 3 and 4) and rice plant (sample No. 5), the results of Table 7 show that the concentration of $\mathrm{Pb}$ higher than the allowed limits of WHO $\left(0.3 \mathrm{mg} \mathrm{Kg}^{-1}\right)$ in all samples at the long of the canal, the higher values were obtained in rice field at the end of canal. This increasing of $\mathrm{Pb}$ in plants may be due to the impact of cars exhaust. Also, domestic and industrial effluents are the major sources of the $\mathrm{Pb}$. While the $\mathrm{Cu}$ and $\mathrm{Zn}$ concentration increased in the beginning of canal in location 1 and 2 than the safe limits of WHO. The other elements were in the allowed limits. This may be due to the growth of these plants in contaminated soil with these elements. Surprisingly, the concentration of these elements in the soil did not exceed the allowable limit of WHO ratio which indicates that the ability of the high absorption of the plant for these elements, even if the concentration was low. Furthermore, this result indicates the seriousness of the growing plants in contaminated soil with this element.

Table 6. Concentrations of some elements in soils irrigated from Abu al-Manja canal (Kilometer from the beginning of the canal).

\begin{tabular}{|c|c|c|c|c|c|c|c|c|c|c|c|}
\hline \multirow{2}{*}{$\begin{array}{l}\text { Sample } \\
\text { No. }\end{array}$} & \multirow{2}{*}{ Location } & \multicolumn{10}{|c|}{ Available concentration elements $\left(\mathrm{mg} / \mathrm{kg}^{-1}\right)$} \\
\hline & & $\mathbf{N}$ & $\mathbf{P}$ & $\mathbf{K}$ & $\mathbf{F e}$ & Mn & Zn & $\mathrm{Cu}$ & $\mathbf{P b}$ & Cd & $\mathbf{N i}$ \\
\hline 1 & K 2.500 & 42.0 & 7.7 & 179.4 & 0.27 & 0.29 & 0.83 & 0.01 & 1.03 & $*<0.1$ & 0.94 \\
\hline 2 & K 7.600 & 65.6 & 2.4 & 214.5 & 0.26 & 0.30 & 0.79 & 0.04 & 0.72 & $*<0.1$ & 0.66 \\
\hline 3 & K 13.950 & 81.2 & 2.2 & 390.0 & 0.40 & 0.22 & 0.59 & 0.02 & 0.74 & 0.03 & 0.68 \\
\hline 4 & K 18350 & 64.4 & 4.8 & 518.7 & 0.32 & 0.22 & 0.68 & 0.03 & 0.83 & $*<0.1$ & 0.73 \\
\hline 5 & & 50.4 & 2.3 & 358.9 & 0.32 & 0.33 & 0.84 & 0.02 & 0.71 & $*<0.1$ & 0.58 \\
\hline
\end{tabular}

Table 7. Concentrations of some elements in plants irrigated with waters of Abu al - Manja canal (Kilometer from the beginning of the canal).

\begin{tabular}{|c|c|c|c|c|c|c|c|c|c|c|c|}
\hline \multirow{3}{*}{$\begin{array}{l}\text { Sample } \\
\text { No. }\end{array}$} & \multirow{3}{*}{ Location } & \multicolumn{10}{|c|}{ Available concentration elements } \\
\hline & & \multicolumn{3}{|c|}{ Percent \% } & \multicolumn{7}{|c|}{$\mathrm{mg} \mathrm{kg}^{-1}$} \\
\hline & & $\mathbf{N}$ & $\mathbf{P}$ & $\mathbf{K}$ & $\mathbf{F e}$ & Mn & $\mathbf{Z n}$ & $\mathrm{Cu}$ & $\mathbf{P b}$ & Cd & $\mathbf{N i}$ \\
\hline$\overline{1}$ & K 2.500 & 0.68 & 0.68 & 1.05 & 448.0 & 138.50 & 743.2 & 230.2 & 4.75 & $*<0.1$ & $*<0.3$ \\
\hline 2 & K 7.600 & 0.58 & 0.86 & 0.73 & 254.5 & 286.75 & 565.2 & 595.2 & 0.50 & $*<0.1$ & $*<0.3$ \\
\hline 3 & K 13.950 & 0.05 & 1.31 & 1.26 & 607.3 & 41.75 & 132.7 & 12.0 & 1.25 & $*<0.1$ & $*<0.3$ \\
\hline 4 & $V 10250$ & 0.04 & 0.81 & 1.14 & 239.0 & 45.75 & 133.5 & 12.7 & 2.50 & $*<0.1$ & $*<0.3$ \\
\hline 5 & K 18.350 & 1.39 & 0.37 & 4.09 & 69.0 & 17.40 & 270.6 & 7.3 & 18.75 & $*<0.1$ & $*<0.3$ \\
\hline
\end{tabular}


Concerning the chemical compositions of the collected water samples form Iskandar drain are given in Tables (8 and 9). The results show that the water samples compared to the canal water, lower than in $\mathrm{pH}$ values $(6.8$ to 7.4), higher than in the ionic content, whereas the electrical conductivity ranged from $1.19-1.42$ dS.m ${ }^{-1}$ (TDS from 761 to $908 \mathrm{ppm}$ ), which considered to be moderately suitable for irrigation purposes according to the
American laboratory. The following ionic dominance order mostly prevailed: $\mathrm{SO}_{4}>\mathrm{HCO}_{3}>\mathrm{Cl}>\mathrm{CO}_{3}: \mathrm{Ca}>\mathrm{Mg}>\mathrm{Na}$ $>\mathrm{K}$. Also, it observed from Table 8, that the calculated of sodium adsorption ratio (SAR) and residual sodium carbonates (RSC) were in the allowed range for using the canal water in irrigation. Whereas the values of SAR for these water samples are ranged from $(0.27-1.13)$ and RSC values were less than zero.

Table 8. Chemical composition of irrigation water samples from along Iskander drain (Kilometer from the beginning of the drain).

\begin{tabular}{|c|c|c|c|c|c|c|c|c|c|c|c|c|c|}
\hline \multirow{2}{*}{$\begin{array}{l}\text { Sample } \\
\text { No. }\end{array}$} & \multirow{2}{*}{ Location } & \multirow{2}{*}{ pH } & \multirow{2}{*}{$\begin{array}{c}E C \\
\left(\mathrm{dS} \mathrm{m}^{-1}\right)\end{array}$} & \multicolumn{4}{|c|}{ Soluble cations (meq. $\mathrm{L}^{-1}$ ) } & \multicolumn{4}{|c|}{ Soluble anions (meq. $\mathbf{L}^{-1}$ ) } & \multirow{2}{*}{ RSC } & \multirow{2}{*}{ SAR } \\
\hline & & & & $\mathrm{Na}^{+}$ & $\mathbf{K}^{+}$ & $\mathrm{Ca}^{++}$ & $\mathbf{M g}^{++}$ & $\mathrm{Cl}^{-}$ & $\mathrm{HCO}_{3}^{-}$ & $\mathrm{CO}_{3}{ }^{=}$ & $\mathrm{SO}_{4}=$ & & \\
\hline 1 & K 0.800 & 6.8 & 1.36 & 3.57 & 0.27 & 4.83 & 5.57 & 1.53 & 5.19 & 1.13 & 6.39 & -4.08 & 1.56 \\
\hline 2 & K 4.500 & 6.8 & 1.42 & 3.39 & 0.32 & 5.00 & 6.04 & 1.63 & 5.28 & 1.13 & 6.71 & -4.63 & 1.44 \\
\hline 3 & K 8.100 & 7.4 & 1.35 & 3.42 & 0.3 & 5.60 & 4.16 & 2.04 & 5.09 & 1.13 & 5.22 & -3.54 & 1.55 \\
\hline 4 & K 12.090 & 7.1 & 1.19 & 3.35 & 0.48 & 3.10 & 3.94 & 2.04 & 3.87 & 0.94 & 4.02 & -2.23 & 1.79 \\
\hline 5 & K 15.000 & 6.9 & 1.41 & 3.22 & 0.37 & 5.69 & 5.03 & 1.53 & 6.04 & 1.13 & 5.61 & -3.55 & 1.39 \\
\hline
\end{tabular}

Data in Table 9 show the concentration of trace elements in water samples of Iskander drain, generally the results indicated that the trace elements higher than the water canal but remain in the safe and allowed levels for irrigation according to WHO, (2004), who stated that the normal water contains lower than 50, 0.05, 1 ppm from iron, zinc and fluoride. Also, the recommended maximum according to FAO (1985) for iron, copper, zinc and manganese concentration for irrigation are $5,0.2,2.0$ and $0.2 \mathrm{ppm}$ respectively. This increase in element concentration may be attributed to contamination comes from maniples effluent discharges which invariably find their usage into agricultural crops.

Table 9. Chemical composition of irrigation water samples from along Iskander drain (Kilometer from the beginning of the drain).

\begin{tabular}{lccccccccccc}
\hline Sample & \multirow{2}{*}{ Location } & \multicolumn{10}{c}{ Available concentration elements (mg L $\mathbf{~}^{-1}$ ) } \\
\cline { 3 - 12 } No. & & N & P & K & Fe & Mn & Zn & Cu & Pb & Cd & Ni \\
\hline 1 & K 0.800 & 9.1 & 3.6 & 10.53 & 0.214 & 0.0349 & 0.434 & $*<0.1$ & 0.068 & $*<0.1$ & 0.024 \\
2 & K 4.500 & 9.7 & 3.5 & 12.48 & 0.215 & 0.0355 & 0.426 & $*<0.1$ & 0.071 & $*<0.1$ & 0.030 \\
3 & K 8.100 & 11.1 & 3.7 & 11.70 & 0.215 & 0.0373 & 0.430 & $*<0.1$ & 0.081 & $*<0.1$ & 0.029 \\
4 & K 12.090 & 10.9 & 3.6 & 18.72 & 0.238 & 0.0415 & 0.431 & $*<0.1$ & 0.070 & $*<0.1$ & 0.031 \\
5 & K 15.000 & 10.7 & 3.7 & 14.43 & 0.202 & 0.0600 & 0.438 & $*<0.1$ & 0.064 & $*<0.1$ & 0.019 \\
\hline
\end{tabular}

Table 10. Chemical properties of the collected soils from Iskander drain area (Kilometer from the beginning of the drain).

\begin{tabular}{|c|c|c|c|c|c|c|c|c|c|c|c|}
\hline \multirow{2}{*}{$\begin{array}{l}\text { Sample } \\
\text { No. } \\
\end{array}$} & \multirow{2}{*}{ Location } & \multirow{2}{*}{$\begin{array}{c}\mathrm{pH} \\
(1: 2.5)\end{array}$} & \multirow{2}{*}{$\begin{array}{c}\mathbf{E C} \\
\mathrm{dSm}^{-1}\end{array}$} & \multicolumn{4}{|c|}{ Soluble cations $\left(\mathrm{meq} \mathrm{L}^{-1}\right)$} & \multicolumn{4}{|c|}{ Soluble anions (meq $\left.\mathbf{L}^{-1}\right)$} \\
\hline & & & & $\mathrm{Na}^{+}$ & $\mathbf{K}^{+}$ & $\mathrm{Ca}^{++}$ & $\mathbf{M g}^{++}$ & $\mathrm{Cl}^{-}$ & $\mathrm{HCO}_{3}^{-}$ & $\mathrm{CO}_{3}$ & $\mathrm{SO}_{4}{ }^{=}$ \\
\hline 1 & K 0.800 & 7.3 & 8.00 & 15.36 & 0.67 & 67.11 & 4.63 & 17.37 & 7.08 & - & 63.32 \\
\hline 2 & K 4.500 & 7.2 & 9.59 & 22.28 & 0.49 & 46.05 & 41.99 & 19.49 & 8.02 & - & 83.30 \\
\hline 3 & K 8.100 & 7.4 & 8.83 & 27.20 & 0.35 & 35.53 & 29.69 & 27.12 & 2.36 & - & 63.29 \\
\hline 4 & K 12.090 & 7.3 & 5.12 & 5.51 & 0.34 & 47.37 & 4.81 & 5.93 & 5.66 & - & 46.44 \\
\hline 5 & V 15000 & 7.4 & 7.89 & 17.59 & 0.46 & 49.02 & 20.28 & 17.48 & 5.78 & - & 64.09 \\
\hline 6 & K 15.000 & 7.4 & 2.07 & 7.40 & 0.24 & 11.18 & 4.03 & 10.59 & 4.25 & - & 8.01 \\
\hline
\end{tabular}

* Cite No 6 cultivated with Rice, the rest cites cultivated with Onion.

Table 11. Physical properties of the collected soils from Iskander drain area(Kilometer from the beginning of the drain).

\begin{tabular}{lccccccccc}
\hline \multirow{2}{*}{$\begin{array}{l}\text { Sample } \\
\text { No. }\end{array}$} & \multirow{2}{*}{ Location } & \multicolumn{2}{c}{ Particle size distribution (\%) } & \multirow{2}{*}{ Textural class } & \multirow{2}{*}{$\begin{array}{c}\text { CaCO }_{3} \\
\text { \% }\end{array}$} & $\begin{array}{c}\text { SP } \\
\text { \% }\end{array}$ & ESP & $\begin{array}{c}\text { CEC } \\
\text { meg/100g }\end{array}$ \\
\hline & K 0.800 & 18.4 & 52.0 & 29.6 & Silt clay loam & 1.45 & 58.0 & 6.98 & 38.17 \\
2 & K 4.500 & 17.4 & 50.0 & 32.6 & Silt clay loam & 3.32 & 63.5 & 3.01 & 39.96 \\
2 & K 8.100 & 16.4 & 49.0 & 34.6 & Silt clay loam & 4.42 & 70.5 & 12.18 & 40.82 \\
3 & K 12.090 & 14.4 & 50.0 & 35.6 & Silt clay loam & 4.85 & 68.0 & 8.41 & 40.95 \\
4 & K 15.000 & 15.4 & 48.0 & 36.6 & Silt clay loam & 4.51 & 67.0 & 14.17 & 41.06 \\
5 & 15.4 & 48.0 & 36.6 & Silt clay loam & 3.74 & 78.0 & 6.61 & 38.72 \\
\hline
\end{tabular}

* Cite No 6 cultivated with Rice, the rest cites cultivated with Onion. 
Table 12. Physical properties of the collected soils from Iskander drain area (Kilometer from the beginning of the drain).

\begin{tabular}{|c|c|c|c|c|c|c|c|c|c|}
\hline \multirow[b]{2}{*}{$\begin{array}{l}\text { Sample } \\
\text { No. }\end{array}$} & \multirow[b]{2}{*}{ Location } & \multirow{2}{*}{$\underset{\mathbf{M g m}^{-3}}{\text { B.D }}$} & \multirow[b]{2}{*}{$\begin{array}{l}\text { T.P } \\
(\%)\end{array}$} & \multirow[b]{2}{*}{$\begin{array}{c}\text { H.C } \\
\mathrm{cm} \mathrm{h}^{-1}\end{array}$} & \multirow[b]{2}{*}{$\underset{\%}{A . W}$} & \multicolumn{4}{|c|}{ Pore size distribution $(\mu \mathrm{m})$} \\
\hline & & & & & & $\begin{array}{c}\text { QDP > } \\
28.8\end{array}$ & $\begin{array}{c}\text { SDP } \\
28.8-8.6\end{array}$ & $\begin{array}{c}\text { WHP } \\
8.6-0.19\end{array}$ & $\begin{array}{c}\text { FCP }< \\
0.19\end{array}$ \\
\hline 1 & K 0.800 & 1.25 & 52.83 & 1.4 & 16.92 & 17.80 & 4.42 & 29.39 & 2.55 \\
\hline 2 & K 4.500 & 1.23 & 53.58 & 1.3 & 12.95 & 18.74 & 4.50 & 29.64 & 2.84 \\
\hline 3 & K 8.100 & 1.20 & 54.71 & 1.8 & 14.32 & 16.37 & 5.31 & 30.45 & 3.71 \\
\hline 4 & K 12.090 & 1.19 & 55.09 & 1.1 & 17.51 & 13.99 & 5.08 & 31.08 & 4.26 \\
\hline 5 & & 1.17 & 55.84 & 1.2 & 18.83 & 12.13 & 4.12 & 32.31 & 4.33 \\
\hline 6 & K 15.000 & 1.14 & 5698 & 13 & 18.73 & 14.32 & 5.54 & 41.70 & 340 \\
\hline
\end{tabular}

Concerning the concentration of some nutrients and heavy metals in soil irrigated by drainage water are present in Table 13, the data show that the concentration in the safe and allowed levels in soil according to FAO (1985) and WHO (2004), but the concentration of most elements higher than the previous soil samples which irrigated with canal water. Higher concentrations of heavy metals in sewage irrigated soil than soil irrigated with uncontaminated water were also reported by (Mitra and Gupta, 1999 and Khurana, et al. 2004).

Table 13. Concentrations of some elements in soils irrigated with waters of Iskander drain (Kilometer from the beginning of the drain).

\begin{tabular}{|c|c|c|c|c|c|c|c|c|c|c|c|}
\hline \multirow{2}{*}{$\begin{array}{l}\text { Sample } \\
\text { No. }\end{array}$} & \multirow[b]{2}{*}{ Location } & \multicolumn{10}{|c|}{ Available concentration elements $\left(\mathrm{mg} / \mathrm{kg}^{-1}\right)$} \\
\hline & & $\mathbf{N}$ & $\mathbf{P}$ & $\mathbf{K}$ & $\mathbf{F e}$ & Mn & $\mathbf{Z n}$ & $\mathbf{C u}$ & $\mathbf{P b}$ & Cd & $\mathbf{N i}$ \\
\hline 1 & K 0.800 & 70.6 & 9.10 & 421.2 & 0.36 & 0.30 & 0.43 & 0.03 & 1.05 & 0.04 & 0.99 \\
\hline 2 & K 4.500 & 51.8 & 1.70 & 456.3 & 0.40 & 0.23 & 0.79 & 0.02 & 0.85 & $*<0.1$ & 0.80 \\
\hline 3 & K 8.100 & 53.2 & 3.10 & 195.0 & 0.40 & 0.31 & 0.83 & 0.01 & 0.68 & $*<0.1$ & 0.64 \\
\hline 4 & K 12.090 & 67.2 & 3.90 & 195.0 & 0.33 & 0.21 & 0.60 & 0.01 & 0.56 & $*<0.1$ & 0.45 \\
\hline 5 & K 15000 & 161.0 & 11.10 & 327.6 & 0.38 & 0.34 & 0.83 & 0.02 & 0.63 & $*<0.1$ & 0.51 \\
\hline 6 & 人 15.000 & 67.2 & 0.10 & 343.2 & 0.33 & 0.38 & 0.43 & 0.01 & 0.94 & $*<0.1$ & 0.81 \\
\hline
\end{tabular}

* Cite No 6 cultivated with Rice, the rest cites cultivated with Onion.

The data presented in Table 14 show the concentration of some elements in plant Onion and Rice samples collected from the area irrigated with Iskander drain. The results $\mathrm{Cu}, \mathrm{Zn}$ and $\mathrm{Pb}$ showed that that higher level in concentration than the allowed level according to
(FAO and WHO); they were likely to be a health hazard to human consumers. They may further lead to toxicity not only to plant and animals but also to consumers through the food chain (FAO/WHO, 2011).

Table 14. Concentrations of some elements in plants irrigated with waters of Iskander drain (Kilometer from the beginning of the drain).

\begin{tabular}{lccccccccccc}
\hline \multirow{2}{*}{$\begin{array}{l}\text { Sample } \\
\text { No. }\end{array}$} & \multirow{2}{*}{ Location } & \multicolumn{3}{c}{ Percent \% } & \multicolumn{7}{c}{ Elements concentration } \\
\cline { 3 - 12 } & & N & P & K & Fe & Mn & Zn & Cu & Pb & Cd & Ni \\
\hline 1 & K 0.800 & 1.14 & 0.43 & 3.08 & 152.2 & 50.50 & 250.5 & 203.7 & 10.50 & $*<0.1$ & $*<0.3$ \\
2 & K 4.500 & 1.25 & 0.86 & 2.73 & 254.5 & 86.75 & 565.2 & 595.2 & 5.50 & $*<0.1$ & $*<0.3$ \\
3 & K 8.100 & 1.75 & 0.95 & 1.26 & 607.3 & 41.75 & 132.7 & 12.0 & 5.25 & $*<0.1$ & $*<0.3$ \\
4 & K 12.090 & 1.75 & 0.81 & 1.14 & 239.0 & 45.75 & 133.5 & 12.7 & 6.50 & $*<0.1$ & $*<0.3$ \\
5 & & 1.39 & 0.37 & 4.09 & 169.0 & 47.40 & 270.6 & 7.3 & 18.75 & $*<0.1$ & $*<0.3$ \\
6 & K 15.000 & 1.25 & 0.65 & 5.08 & 142.2 & 40.50 & 150.5 & 103.7 & 14.50 & $*<0.1$ & $*<0.3$ \\
\hline
\end{tabular}

* Cite No 6 cultivated with Rice, the rest cites cultivated with Onion.

It can be concluded that, the greatest changes of water chemical properties are frequently results from human activities, because these may alter water chemistry, clarity and temperature, factors linked with species changes. The high concentrations recorded of the studied elements are mainly attributed to the agricultural, urban discharge and industrial effluents. The study recommends the periodically monitoring of canals and drains water of study area specially the heavy metal concentration.

\section{REFERENCES}

Abdel-Mawgoud, A. S. A. (2005). Water quality Appraisal for soil-water behavior in irrigated clay soil, Egypt. Ninth International Water Technology Conference, IWTC9 2005, Sharm El-Sheikh, Egypt, 1245 1256.
Alghobar, M. A., and S. Suresha (2017). Evaluation of metal accumulation in soil and tomatoes irrigated with sewage water from Mysore city, Karnataka, India. Journal of the Saudi Society of Agricultural Sciences. 16, 49-59.

Alobaidy, A. H. M. J., M. A. Al-Sameraiy, A. J. Kadhem and A. Abdul Majeed (2010). Evaluation of treated municipal wastewater quality for irrigation. Journal of Environmental Protection, 1, 216-225.

American Public Health Association (APHA). (1995). "Standard Methods for the Examination for Water and Wastewater" (19th edition). Byrd Prepess Springfield, Washington.

Davis, S. N., and R. J. M. Dewiest (1966). "Hydrogeology". John Wiley \& Sons. Inc., New York. p:463. 
El Bouraie, M. M., E. A. Motawea, G.G., Mohamed and M. M. Yehia (2011). Water quality of Rosetta branch in Nile Delta, Egypt. Suoseura - Finnish Peatland Society, ISSN 0039-5471, Suo 62(1): 3137.

Emdad, M. R., M. Shahabifar and H. Fardad (2006). Effect of different water qualities on soil physical properties. Tenth International Water Technology Conference, IWTC10,647- 652.

FAO (1985). Water Quality for Agriculture, R.S. Ayers \& D.W. Westcot (Ed.), Irrigation and drainage paper 29 Rev. 1, pp 1-174, FAO Rome.

FAO/WHO, (2011). Evaluation of certain food additives and contaminants. Technical Reports Series $\mathrm{N}^{\circ}$ $960,162$.

Goher, M. E., A. M. Hassan, I. A. Abd El-Moniem, A. H. Fahmy and S. M. Elsayed (2014). Evaluation of surface water quality and heavy metal indices of Ismailia Canal, Nile River, Egypt. Egyptian Journal of Aquatic Research 2014 40, 225-233.

Gupta, N., D. K. Khan and S. C. Santra (2008). An assessment of heavy metal contamination in vegetables grown in wastewater-irrigated areas of Titagarh, West Bengal, India. Bull Environ. Contam. Toxicol. 80, 115-118.

Harivandi, M. A. (1999). Interpreting turfgrass irrigation water test results. Publication 8009 . University of California Division of Agriculture and Natural Resources, Oakland, Calif.

Horneck, D. A., D. M. Sullivan, J. S. Owen, and J. M. Hart. (2011). Soil test interpretation guide. EC 1478. Oregon State Univ. Ext. Serv., Corvallis.

Khan, S., Q. Cao, Y. M. Zheng, Y. Z. Huang and Y. G. Zhu (2008). Health risks of heavy metals in contaminated soils and food crops irrigated with wastewater in Beijing, China. Environmental Pollution 152, 686 - 692.

Khaskhoussy, K., M. Hachicha, B. Kahlaoui, B. MessoudiNefzi, A. Rejeb, O. Jouzdan and A. Arselan (2013). Effect of treated wastewater on Soil and Corn Crop in the Tunisian Area. J. Appl. Sci. Res., 9(1): 132140.

Khurana, J. P., U. Dasgupta, A. Laxmi, D. umar and L. K. Paul (2004). Light control of plant development by phytochromes: a perspective. Proc Indian Natl Sci Acad Part B Biol Sci 70: 379-411.
Klute, A. (1986). Methods of soil analysis, Part 1, 2nd ed., Agronomy Monograph 9. ASA and SSSA, Madison.

Malla, R., Y. Tanaka, K. Mori and K.L. Totawat (2007). Effect of short-term sewage irrigation on chemical build up in soils and vegetables. The Agricultural Engineering International: theCIGR Ejournal. Manuscript LW 07006 Vol. IX.

Mitra, A. and S. K. Gupta (1999). Effect of sewage water irrigation on essential plant nutrient and pollutant element status in a vegetable growing area around Calcutta. J. Indian Soc. Soil Sci. 47:99-105. Mosleh YYI, Almagrabi OA (2013). Heavy metal accumulation in some vegetables irrigated with treated water. Int. J. Green Her. Chem. 2(1):81-90.

Page, A. L., R. H. Miller and D. R. Keeny (1982). "Methods of soil analysis". Part $\pi$. Chemical and microbiological properties (2nd ed.) Amer. Soc. Agron. Monograph no. 9 Madison, Wisconsin, USA.

Pandey, S. N. (2006). Accumulation of heavy metals (Cd, $\mathrm{Cr}, \mathrm{Cu}, \mathrm{Ni}$ and $\mathrm{Zn}$ ) in Raphanus sativus L.and Spinacia oleracea L. plants irrigated with industrial effluent. Journal of Environmental Biology, 27(2) 381-384.

Saffari, V. R. and M. Saffari (2013). Effect of treated municipal wastewater on bean growth, soil chemical properties, and chemical fractions of zinc and copper. Arab J. Geosci. 6, 4475-4485.

Singh,A. and M. Agrawal (2012). Effects of waste water irrigation on physical and biochemical characteristics of soil and metal partitioning in Beta vulgaris L. Agric Res (October-December 2012) 1(4):379-391.

Subramani,T., M. Mangaiyarkarasi and C. Kathirvel (2014). Impact of Sewage and Industrial Effluents on Soil-Plant Health Implementation of training programs. Journal of Engineering Research and Applications. ISSN: 2248-9622, Vol. 4, Issue 6(Version 2), pp.270-273.

Todd, D.K. and L.W. Mays (2004): Groundwater hydrology, 3rd ed., John Wiley and Sons Inc., New York, $613 \mathrm{p}$.

WHO, (2004). "Guidelines for Drinking-Water Quality". Third edition, vol. 1: Recommendations. World Health Organization, Geneva.

\footnotetext{
تأثير الرى بمياه مختلفة المصدر على خواص التزبة والتبات بمحافظة القليوبية، مصر

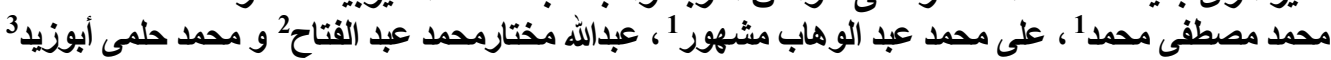

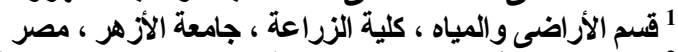

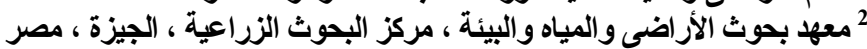

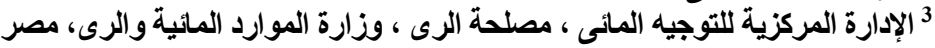

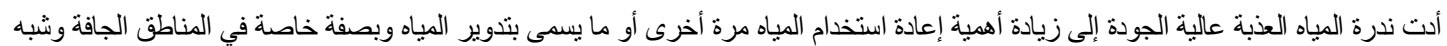

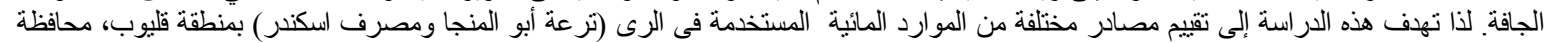

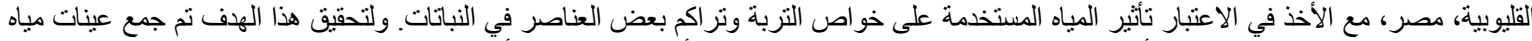

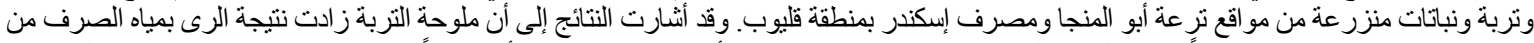

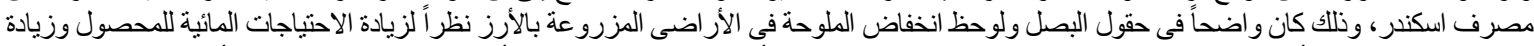

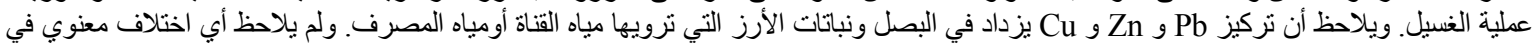

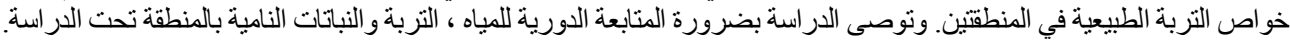

